\title{
Medical Treatment of Cushing's Disease: Somatostatin Analogues and Pasireotide
}

\author{
Alberto M. Pedroncelli \\ Novartis Pharma AG, Basle, Switzerland
}

\section{Key Words}

Pasireotide $\cdot$ Somatostatin analogue $\cdot$ Cushing's disease

\begin{abstract}
Cushing's disease is Cushing's syndrome caused by an adrenocorticotropic hormone-secreting pituitary adenoma and, in the absence of adequate treatment, can be fatal. Cushing's disease represents an unmet medical need, with no approved medical therapies. Pasireotide is a novel multi-receptor-targeted somatostatin analogue with high affinity for $\mathrm{sst}_{1,2,3}$ and $\mathrm{sst}_{5}$. Compared with octreotide, pasireotide has an in vitro binding affinity 40-, 30- and 5 -fold higher for $\mathrm{sst}_{5}$, sst $_{1}$ and sst $_{3}$, respectively, and 2-fold lower for sst $_{2}$. Adrenocorticotropic hormone-secreting pituitary adenomas predominantly express $\mathrm{sst}_{5}$, followed by $\mathrm{sst}_{2}$ and $\mathrm{sst}_{1}$, suggesting that pasireotide may be effective in the treatment of Cushing's disease. In a 15-day phase II trial of pasireotide 600 $\mu$ s.c. b.i.d. in patients with de novo or persistent/recurrent Cushing's disease, 22 of 29 patients (76\%) achieved reduced urinary free cortisol (UFC) levels, 5 of whom (17\%) achieved normalized UFC. Patients who achieved normalized UFC had a significantly greater reduction in serum cortisol than those who did not $(p=0.04)$, and minimum pasireotide plasma concentrations appeared to be higher in responders. Based on these results, a randomized, double-blind phase III study comparing pasireotide $600 \mu \mathrm{g}$ b.i.d. and $900 \mu \mathrm{g}$ b.i.d. was initiated and is ongoing. This is the largest ever phase III study in patients with Cushing's disease. The primary end point of this study is normalization of UFC after 6 months of
\end{abstract}

treatment. Finally, preliminary results from a study on $17 \mathrm{pa}$ tients with Cushing's disease suggest that the combined use of pasireotide, cabergoline and low-dose ketoconazole may have additive beneficial effects in the medical treatment of Cushing's disease.

Copyright $\odot 2010$ S. Karger AG, Basel

\section{Introduction}

Endogenous Cushing's syndrome can be caused by tumors of the adrenal glands that produce excess cortisol, known as autonomous adrenal hypercortisolism, secretion of adrenocorticotropic hormone (ACTH) or corticotropin-releasing hormone (CRH) from non-pituitary tumors, known as ectopic ACTH or CRH secretion or, most frequently, by an ACTH-secreting pituitary adenoma, which is known as Cushing's disease [1]. Excessive secretion of ACTH by a pituitary corticotropic adenoma results in excessive cortisol secretion from the adrenal glands, which can result in weight gain, high blood pressure, depression, cognitive impairment, severe fatigue and muscle weakness, purplish skin striae, hyperpigmentation, loss of libido, impaired glucose metabolism, hirsutism, acne and menstrual disorders [2, 3]. Chronic hypercortisolism is associated with an increased incidence of systemic arterial hypertension, diabetes mellitus, central obesity, hyperlipidemia and hypercoagulability [2]. In the absence of adequate treatment, Cushing's disease can be a fatal condition [4]; patients with Cushing's dis-

\section{KARGER}

Fax +4161306 1234 E-Mail karger@karger.ch www.karger.com
(C) 2010 S. Karger AG, Basel

0028-3835/10/0925-0120\$26.00/0

Accessible online at:

www.karger.com/nen
A.M. Pedroncelli

Novartis Oncology, Forum 1, Novartis Campus

$\mathrm{CH}-4056$ Basle (Switzerland)

Tel. +41 61324 0486, Fax +41 61696 3089, E-Mail alberto.pedroncelli@ novartis.com 
ease have a mortality rate four times higher than age- and sex-matched controls [2].

Treatment goals in Cushing's disease include the reversal of clinical features, the normalization of biochemical changes with minimal morbidity, and long-term control without recurrence [1]. First-line treatment for Cushing's disease is pituitary surgery. Second-line options include repeat surgery, radiotherapy, bilateral adrenalectomy and medical therapy. Currently, there are no approved medications for the treatment of Cushing's disease. The most commonly used medical therapies, such as ketoconazole, metyrapone and mitotane, target the adrenal glands and, therefore, do not treat the underlying cause of the disease or restore normal function of the hypothalamo-pituitary-adrenal axis [5]. The commercially available somatostatin analogue octreotide is mostly ineffective in treating Cushing's disease [6-8].

\section{Pasireotide, a Multi-Receptor Targeted Somatostatin Analogue}

Pasireotide is a novel multi-receptor-targeted somatostatin analogue with high binding affinity to somatostatin receptor subtypes sst ${ }_{1,2,3}$ and sst $_{5}$. Octreotide has high affinity for somatostatin receptor subtype sst ${ }_{2}$ and marginal affinity for sst ${ }_{5}$, which accounts for its efficacy in treating patients with acromegaly and symptomatic gastroenteropancreatic neuroendocrine tumors (GEPNETs), and can partly explain its lack of efficacy in Cushing's disease [9]. Compared with octreotide, pasireotide has an in vitro binding affinity 40-, 30- and 5-fold higher for sst ${ }_{5}$, sst $_{1}$ and sst ${ }_{3}$, respectively, and 2-fold lower for sst $_{2}$ [10]. Because of these differences in binding affinity, it can be speculated that in cells and tissues that express somatostatin receptors other than $s t_{2}$, pasireotide will have a stronger inhibitory effect on hormone secretion than octreotide. ACTH-secreting pituitary adenomas predominantly express $s{ }_{5}$, followed by $s t_{2}$ and sst $_{1}[11$, 12]. Therefore, by targeting multiple somatostatin receptor subtypes, pasireotide may prove to be effective not only in patients with acromegaly or GEP-NETs, but also in patients with Cushing's disease.

\section{Preclinical Evidence}

In vitro evaluation of a mouse corticotropic adenoma cell line (AtT-20 cells) showed high mRNA expression of sst $_{5}$ receptors but few sst $_{2}$ receptors, reflecting the expres- sion profile of human corticotropic adenomas [13]. Furthermore, in vitro studies in human ACTH-secreting pituitary adenomas and AtT-20 murine corticotropic tumor cells showed that pasireotide inhibits basal and stimulated ACTH release. A 72-hour incubation with pasireotide $10 \mathrm{nM}$ in human corticotropic adenoma cells resulted in inhibition of ACTH release in three of five cultures $(-30 \%$ to $-40 \%)$, whereas octreotide $10 \mathrm{nM}$ inhibited ACTH release in only one culture (-28\%) [14]. Importantly, the suppression of CRH-induced ACTH release exhibited by pasireotide in AtT-20 cells was unaffected by a 48-hour pretreatment with dexamethasone. By contrast, the suppressive effects of octreotide were almost completely blocked by dexamethasone [14, 15], suggesting that $\mathrm{sst}_{2}$ may be downregulated by glucocorticoid treatment (or by elevated endogenous cortisol levels), and that $s t_{5}$ is more resistant to downregulation. This also suggested that by inhibiting ACTH release and subsequent cortisol levels via sst ${ }_{5}$, the expression of sst $_{2}$ may be restored, thus further enhancing ACTH inhibition by an $\mathrm{sst}_{2} / \mathrm{sst}_{5}$ receptor ligand such as pasireotide.

\section{Clinical Evidence}

\section{Pasireotide as Monotherapy}

In order to assess the effects of pasireotide in patients with Cushing's disease, a 15-day phase II, open-label, single-arm, multicenter, proof-of-concept trial was initiated [16]. Patients were aged $\geq 18$ years and had clinically and biochemically confirmed Cushing's disease, which was established by the mean of two consecutive 24-hour urinary free cortisol (UFC) levels $\geq 2$ times the upper limit of normal, morning plasma ACTH levels within or above the normal range, and either MRI confirmation of a pituitary macroadenoma (adenoma $\geq 1 \mathrm{~cm}$ ) or an inferior petrosal sinus gradient $>3$ after $\mathrm{CRH}$ stimulation. The primary efficacy outcome was normalization of mean UFC levels after 15 days of treatment. Secondary end points included changes in plasma $\mathrm{ACTH}$ and serum cortisol, pharmacokinetic evaluation and safety.

Thirty-nine patients self-administered pasireotide s.c. $600 \mu \mathrm{g}$ twice daily for 15 days. Of the 29 patients in the primary efficacy analysis, $22(76 \%)$ showed a reduction in UFC levels, of whom 5 (17\%) had normal UFC levels (UFC responders), after 15 days of treatment with pasireotide (fig. 1). Overall, the mean UFC level decreased from baseline by $44.5 \%(\mathrm{p}=0.021)$. The mean \pm SD UFC level decreased from $1,231 \pm 1,141 \mathrm{nmol} / 24 \mathrm{~h}[446 \pm 413$ 
Fig. 1. Baseline and day 15 (study end) mean UFC level in each patient (mean of two 24-hour UFC level measurements). The dashed line indicates the upper limit of the normal range. Responding patients (defined as having a UFC level within the normal range at study end) are indicated by the arrows [16]. ${ }^{\circ} 2009$ The Endocrine Society. Reproduced with permission.

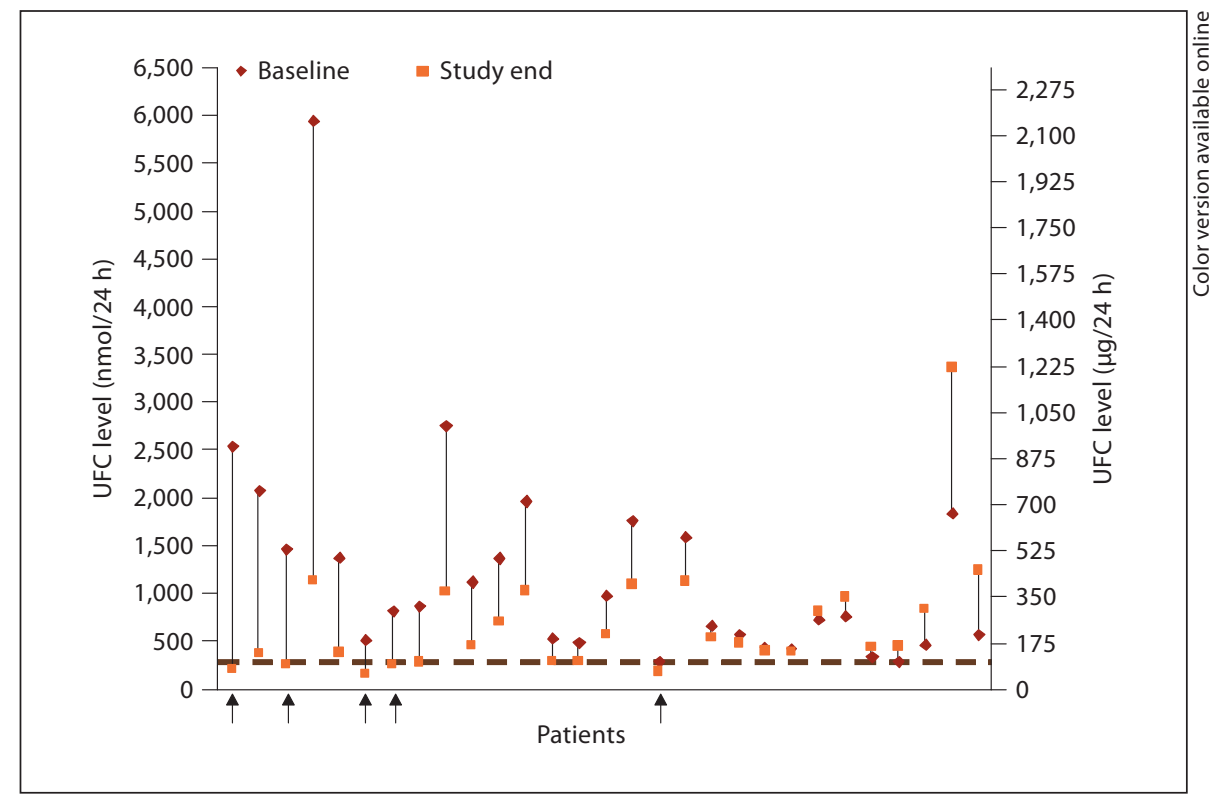

Table 1. Pharmacokinetic parameters of pasireotide $600 \mu \mathrm{g}$ s.c. b.i.d. on days 1, 5, 12 and 15 in patients with Cushing's disease

\begin{tabular}{lcccr}
\hline Parameter & $\begin{array}{l}\text { Day 1 } \\
(\mathrm{n}=36)\end{array}$ & $\begin{array}{l}\text { Day 5 } \\
(\mathrm{n}=38)\end{array}$ & $\begin{array}{l}\text { Day 12 } \\
(\mathrm{n}=38)\end{array}$ & $\begin{array}{l}\text { Day 15 } \\
(\mathrm{n}=33)\end{array}$ \\
\hline $\mathrm{C}_{\min }, \mu \mathrm{g} / \mathrm{l}$ & 0 & $3.9 \pm 2.2$ & $5.1 \pm 4.2$ & $\begin{array}{r}4.9 \pm 2.7 \\
\mathrm{C}_{\max }, \mu \mathrm{g} / \mathrm{l}\end{array}$ \\
$\begin{array}{r}13.8 \pm 4.5 \\
\mathrm{~T}_{\max }, \mathrm{h}\end{array}$ & $\begin{array}{r}20.8 \pm 11.7 \\
2(2-4)\end{array}$ & $\begin{array}{r}20.5 \pm 6.9 \\
2(2-4)\end{array}$ & $\begin{array}{r}21.1 \pm 6.9 \\
2(2-2)\end{array}$ & $2(2-2)$ \\
$\begin{array}{c}\mathrm{AUC} C_{0-8 \mathrm{~h}} \\
\mu \mathrm{g} \cdot \mathrm{h} / \mathrm{l}\end{array}$ & $51.7 \pm 16.0$ & $87.0 \pm 34.2$ & $94.5 \pm 37.4$ & $98.9 \pm 33.9$ \\
\hline
\end{tabular}

$\mathrm{C}_{\min }, \mathrm{C}_{\max }$ and $\mathrm{AUC}_{0-8 \mathrm{~h}}$ values are expressed as mean $\pm \mathrm{SD}$. $\mathrm{T}_{\max }$ values are expressed as median (range). $\mathrm{C}_{\min }=$ Minimum plasma concentration; $\mathrm{C}_{\max }=$ maximum plasma concentration; $\mathrm{T}_{\max }=$ time to $\mathrm{C}_{\max } ; \mathrm{AUC}_{0-8 \mathrm{~h}}=$ area under the plasma concentration-time curve from 0 to $8 \mathrm{~h}$. ${ }^{\odot} 2009$ The Endocrine Society. Reproduced with permission.

$\mu \mathrm{g} / 24 \mathrm{~h}]$ at baseline to $683 \pm 615 \mathrm{nmol} / 24 \mathrm{~h}[248 \pm 223$ $\mu \mathrm{g} / 24 \mathrm{~h}$ ] at study end $(\mathrm{p}=0.013)$ [16].

Patients who achieved normalized UFC levels had a significantly greater reduction in serum cortisol than patients who did not. The mean baseline area under the plasma concentration-time curve from $0-8 \mathrm{~h}\left(\mathrm{AUC}_{0-8 \mathrm{~h}}\right)$ of serum cortisol was $5,046 \mathrm{nmol} \cdot \mathrm{h} / \mathrm{l}$. A significant difference in serum cortisol reduction from day -1 to day 15 was observed in UFC responders compared with UFC nonresponders (serum cortisol reduction of 1,248 vs. 420 $\mathrm{nmol} \cdot \mathrm{h} / \mathrm{l}, \mathrm{p}=0.04)[16]$.
Steady-state levels of pasireotide were achieved within 5 days of treatment initiation, and the minimum plasma concentration $\left(\mathrm{C}_{\min }\right)$ of pasireotide on day 15 was above the theoretical $\mathrm{C}_{\min }(>1 \mu \mathrm{g} / \mathrm{l})$ required to demonstrate efficacy (table 1). Furthermore, $\mathrm{C}_{\min }$ and $\mathrm{AUC}_{0-8 \mathrm{~h}}$ values of pasireotide appeared to be higher in responders than nonresponders. The mean $\pm \mathrm{SD} \mathrm{C}_{\min }$ in responders $(\mathrm{n}=$ 5) was $7.8 \pm 4.1 \mu \mathrm{g} / \mathrm{l}$, which was $\sim 1.8$ times higher than that in nonresponders $(4.3 \pm 2.4 \mu \mathrm{g} / \mathrm{l} ; \mathrm{n}=22)$, and the mean $\pm \mathrm{SD} \mathrm{AUC}_{0-8 \mathrm{~h}}$ in responders was $119 \pm 32.5$ $\mu \mathrm{g} \cdot \mathrm{h} / \mathrm{l}$, which was $\sim 1.3$ times higher than that in nonresponders, $93.3 \pm 38.3 \mu \mathrm{g} \cdot \mathrm{h} / \mathrm{l}[16]$.

Pasireotide was generally well tolerated, with $87 \%$ of patients experiencing an adverse event considered to be drug related, the majority of which were mild and gastrointestinal in origin. The most common adverse events were diarrhea (44\%), nausea (23\%) and abdominal pain (18\%). Hyperglycemia occurred in 14 patients (36\%), most of whom $(\mathrm{n}=12)$ experienced mild hyperglycemia. Of the 14 patients, three had a documented medical history of diabetes mellitus and two of impaired fasting glucose at baseline [16].

Based on these encouraging phase II results, a large, randomized, double-blind phase III trial comparing pasireotide $600 \mu$ g s.c. b.i.d. and $900 \mu$ g s.c. b.i.d. in patients with de novo or persistent/recurrent Cushing's disease was initiated and is ongoing. This is the largest ever phase III study in patients with Cushing's disease. The primary end point of this study is normalization of UFC after 6 
months of treatment. Key secondary end points include the proportion of responders at months 3 and 12, mean change in 24-hour UFC, plasma ACTH and serum cortisol, changes in QoL, and changes in signs and symptoms of Cushing's disease.

\section{Combination Medical Therapy with Pasireotide}

In Cushing's disease, medical therapy with adrenalblocking agents is often used as pretreatment before surgery and after unsuccessful surgery and radiotherapy, although there is limited robust evidence for their efficacy [1]. Adrenal-blocking agents include metyrapone, mitotane, aminoglutethamide, etomidate and ketoconazole. Ketoconazole is the most often used adrenolytic agent and works by inhibiting cytochrome P450-dependent enzymes of steroidogenesis.

There have also been recent studies evaluating the use of the dopamine agonist cabergoline as a treatment for Cushing's disease, either alone [17] or in combination with ketoconazole [18]. These studies showed that up to 2-years' monotherapy with cabergoline results in UFC normalization in approximately one third of patients, whereas adding ketoconazole to cabergoline therapy can increase the proportion of patients with normalized UFC to approximately two thirds of patients $[17,18]$.

More recently, an 80-day clinical trial in 17 patients with Cushing's disease was initiated to examine the efficacy of a stepwise approach to medical therapy, with pasireotide as the basal treatment modality, sequentially extended with cabergoline and ketoconazole [19]. Patients started treatment with pasireotide $100 \mu \mathrm{g}$ s.c. t.i.d. If UFC had not normalized at day 15 , the pasireotide dose was increased to $250 \mu$ g s.c. t.i.d. At day 32 , patients with elevated UFC added cabergoline $1.5 \mathrm{mg}$ q.i.d. At day 60, those patients who still had elevated UFC added ketoconazole $200 \mathrm{mg}$ t.i.d.

Preliminary results suggest that the combined use of pasireotide, cabergoline and low-dose ketoconazole may have additive beneficial effects in the medical treatment of Cushing's disease [19].

\section{Conclusion}

Pasireotide is a promising new pituitary-targeted treatment for patients with Cushing's disease. Results from the large, randomized, double-blind, phase III trial will help to determine the role pasireotide will play in the treatment of Cushing's disease. Furthermore, the combination of partially independent medical therapies which act through differential mechanisms is a rational approach to the treatment of Cushing's disease.

\section{Acknowledgements}

The author thanks Keri Wellington, PhD, Mudskipper Bioscience, for medical editorial assistance with the manuscript. Financial support for medical editorial assistance was provided by Novartis Pharmaceuticals Corporation.

\section{Disclosure Statement}

Alberto M. Pedroncelli is an employee of Novartis Pharma AG, Basel, Switzerland.

\section{References}

1 Biller BMK, Grossman AB, Stewart PM, Melmed S, Bertagna X, Bertherat J, Buchfelder M, Colao A, Hermus AR, Hofland LJ, Klibanski A, Lacroix A, Lindsay JR, NewellPrice J, Nieman LK, Petersenn S, Sonino N, Stalla GK, Swearingen B, Vance ML, Wass JA, Boscaro M: Treatment of ACTH-dependent Cushing's syndrome: a consensus statement. J Clin Endocrinol Metab 2008;93: 2454-2462.

-2 Arnaldi G, Angeli A, Atkinson AB, Bertagna X, Cavagnini F, Chrousos GP, Fava GA, Findling JW, Gaillard RC, Grossman AB, Kola B, Lacroix A, Mancini T, Mantero F, Newell-Price J, Nieman LK, Sonino N, Vance
ML, Giustina A, Boscaro M: Diagnosis and complications of Cushing's syndrome: a consensus statement. J Clin Endocrinol Metab 2003;88:5593-5602.

- 3 Findling JW, Raff H: Cushing's syndrome: important issues in diagnosis and management. J Clin Endocrinol Metab 2006;91: 3746-3753.

4 Dekkers OM, Biermasz NR, Pereira AM, Roelfsema F, van Aken MO, Voormolen JH, Romijn JA: Mortality in patients treated for Cushing's disease is increased, compared with patients treated for nonfunctioning pituitary macroadenoma. J Clin Endocrinol Metab 2007;92:976-981.
5 Newell-Price J, Bertagna X, Grossman AB, Nieman LK: Cushing's syndrome. Lancet 2006;367:1605-1617.

6 Ambrosi B, Bochicchio D, Fadin C, Colombo P, Faglia G: Failure of somatostatin and octreotide to acutely affect the hypothalamicpituitary-adrenal function in patients with corticotropin hypersecretion. J Endocrinol Invest 1990;13:257-261.

7 Lamberts SW, Uitterlinden P, Klijn JM: The effect of the long-acting somatostatin analogue SMS 201-995 on ACTH secretion in Nelson's syndrome and Cushing's disease. Acta Endocrinol (Copenh) 1989;120:760766. 
8 Invitti C, De Martin M, Brunani A, Piolini M, Cavagnini F: Treatment of Cushing's syndrome with the long-acting somatostatin analogue SMS 201-995 (sandostatin). Clin Endocrinol (Oxf) 1990;32:275-281.

$\checkmark 9$ Comi RJ: Octreotide: a 15-year update. Endocrinologist 2006;16:86-90.

-10 Bruns C, Lewis I, Briner U, Meno-Tetang G, Weckbecker G: SOM230: a novel somatostatin peptidomimetic with broad somatotropin release inhibiting factor (SRIF) receptor binding and a unique antisecretory profile. Eur J Endocrinol 2002;146:707-716.

-11 Hofland LJ, Lamberts SW: Somatostatin receptors in pituitary function, diagnosis and therapy. Front Horm Res 2004;32:235-252.

12 Hofland LJ: Somatostatin and somatostatin receptors in Cushing's disease. Mol Cell Endocrinol 2008;286:199-205.

13 Schmid HA, Tran LL, Wang Y, Glusman JE: Preclinical and clinical experience with the novel multi-ligand somatostatin analog, SOM230 (abstract). Endocr Pract 2005;11: 836
14 Hofland LJ, Van Der Hoek J, Feelders R, van Aken MO, van Koetsveld PM, Waaijers M, Sprij-Mooij D, Bruns C, Weckbecker G, de Herder WW, Beckers A, Lamberts SWJ: The multi-ligand somatostatin analogue SOM230 inhibits ACTH secretion by cultured human corticotroph adenomas via somatostatin receptor type 5. Eur J Endocrinol 2005;152:645-654.

15 Van Der Hoek J, Waaijers M, van Koetsveld PM, Sprij-Mooij D, Feelders RA, Schmid HA Schoeffter P, Hoyer D, Cervia D, Taylor JE, Culler MD, Lamberts SW, Hofland LJ: Distinct functional properties of native somatostatin receptor subtype 5 compared with subtype 2 in the regulation of ACTH release by corticotroph tumour cells. Am J Physio Endocrinol Metab 2005;289:E278-E287.

-16 Boscaro M, Ludlam WH, Atkinson B, Glusman JE, Petersenn S, Reincke M, Snyder P, Tabarin A, Biller BM, Findling J, Melmed S, Darby CH, Hu K, Wang Y, Freda PU, Grossman AB, Frohman LA, Bertherat J: Treatment of pituitary dependent Cushing's disease with the multi-receptor ligand somatostatin analog pasireotide (SOM230): a multicenter, phase II trial. J Clin Endocrinol Metab 2009;94:115-122.
17 Pivonello R, De Martino MC, Cappabianca P, De LM, Faggiano A, Lombardi G, Hofland LJ, Lamberts SW, Colao A: The medical treatment of Cushing's disease: effectiveness of chronic treatment with the dopamine agonist cabergoline in patients unsuccessfully treated by surgery. J Clin Endocrinol Metab 2008;94:223-230.

-18 Vilar L, Naves LA, Azevedo MF, Arruda MJ, Arahata CM, Moura E Silva, Agra R, Pontes L, Montenegro L, Albuquerque JL, Canadas V: Effectiveness of cabergoline in monotherapy and combined with ketoconazole in the management of Cushing's disease. Pituitary 2010;13:123-129.

19 Feelders R, de Bruin C, Pereira AM, NeteaMaier RT, Hermus A, Zelissen PM, de Jong FH, van der Lely AJ, de Herder WW, Hofland LJ, Lamberts SW: Stepwise medical treatment of Cushing's disease in a prospective, open label, multi-center trial: pasireotide mono- or combination therapy with a dopamine agonist and low-dose ketoconazole induces biochemical remission in 13 out of 15 patients (abstract S21-S25); in 91st Annu Meet Endocrine Soc, Washington, 2009. 